\title{
AYURLOG
}

National Journal of Research in Ayurved Science

http://www.ayurlog.com

Nov- 2020 | Volume 08 ${ }^{\text {th }} \mid$ Issue: $6^{\text {th }}$

ISSN: 2320-7329

\section{Review on Tambulasava - A fermented Ayurvedic formulation}

\author{
Baban Rathod ${ }^{1}$, Sachin Sheth ${ }^{2}$, Vishakha Vivek Sonawane ${ }^{*^{3}}$, \\ Professor $^{1}$, Assistant Professor ${ }^{2}$, P.G. Scholar ${ }^{3}$, \\ Dept. of Rasashastra and Bhaishajya Kalpana, \\ APM's Ayurved Mahavidyalaya, Sion, Mumbai, Maharashtra, India \\ *Corresponding author: email id: vizisonawane13@gmail.com
}

\begin{abstract}
Sandhana Kalpana, a biomedical fermentation process is an important dosage form of Ayurveda, in practice since ages. Asava-Arishtas are the main products of Sandhana kalpana. The self generated alcohol generated during Sandhan Kalpana acts as a solvent for extraction of active principles from the raw drugs and also acts as preservative. Tambulasava is one of the unique and unexplored fermented preparation mentioned in Gadanigraha. The present study mainly deals with the Pharmaceutical preparation of Tambulasava and its indications in detail.
\end{abstract}

Keywords: Tambulasava, Gadanigraha, Sandhana Kalpana, Asava.

\section{INTRODUCTION:}

Sandhana Kalpana is a complex biotechnological process based on phenomenon of fermentation.Ancient acharyas developed it with great combination of physical and chemical engineering. It plays an important role in making these preparations more superior from pharmaceutical as well as therapeutic point of view.

Asavas and Arishtas, the main products of Sandhana Kalpana are quite popular in the community of Ayurvedic physicians. Though these two terms are interblended in the classics, but they are having separate origin from two different basic Kalpanas i.e. Swaras and Kwatha and hence they cannot be considered as synonyms. Asava-arishtas are unique contribution of Ayurveda and a novel dosage form. They are cost-effective, economical with great advantages like long shelf life, palatability, effective in smaller doses and further they require less quantity of drug, less equipment and even less man power for their preparation. Hence, a successful invention to conquer all the short 
comings of five basic kalpanas.

Many types of Sandhana kalpas are mentioned in the ancient Samhitas, many kalpas have similiar names but their method of preparation differs from each other. Tambulasava is a different and unique combination mentioned in the text Gadanigraha. This is the only asava that contains Tambula leaves as its main content. Tambulasava is the important formulation of Gadanigraha. Its indications are Arsharoga, Kaphodbhava Roga, Rasayana, Ashmariroga. It contains $6-12 \%$ of selfgenerated alchohol. This medicine is deepana, pachana in nature, and is also indicated in Kaphodbhava rogas.

\section{Aim and Objectives:}

1. To study the Pharmaceutical preparation and indications of Tambulsava from Gadanigraha.

2. Pharmaceutical Preparation of Tambulsava.

\section{HISTORICAL REVIEW:}

Tambulasava is a formulation mentioned only in Gadanigraha. It has no other Pathbhedas. It is mentioned in Arsha Rogadhikaara of Gadanigraha Prayog khanda-1. ${ }^{[1]}$

\section{Gadanigraha:}

GadaNigraha is one of the ancient text of Ayurveda written by Acharya Shodhala in $12^{\text {th }}$ century. It presents most of the

Table 1.1 showing ingredients of Tambulasava ${ }^{[2]}$ : theoretical edifice of Ayurveda and concentrates mainly on different formulations, their preparations and indications. Gada Nigraha, a noteworthy and important medieval Ayurvedic work of Shodala is composed in two distinct parts and contains about 10,054 (2,700+7,354) verses. The first part is a collection of formulae arranged according to the several types Of pharmaceutical preparations and the second one is a comprehensive text dealing with both Nidana and Chikitsa, arranged as per the Astangas (8 major divisions) of Ayurveda.

In this text Part 1, a total of 60 AsavaArishtas (fermented drugs) are mentioned in the chapter Asavadhikar. Different pharmacodynamic actions of drugs are elaborated, wherein the therapeutic potential of Sandhana kalpana is also mentioned.Among them Tambulasava is one of the formulation mentioned.

\section{MATERIALS AND METHODS :}

\section{Collection, Identification and Authentication of raw materials:}

Raw materials were collected from local market.

Identification and Authentication of raw materials was done from certified lab. 


\begin{tabular}{|c|c|c|c|c|}
\hline Sr. No. & Name & Latin Name & Part Used & $\begin{array}{c}\text { Quantity } \\
\text { (mentioned in text) }\end{array}$ \\
\hline 1 & Dhataki & $\begin{array}{l}\text { Woodfordia } \\
\text { fructicosa }\end{array}$ & Flower & 7 Pala \\
\hline 2 & Pugaphala & Areca nut & Fruit & 10 Pala \\
\hline 3 & Khadir & Acacia catechu & Bark & 10 Pala \\
\hline 4 & $\begin{array}{c}\text { Tambul (cultivar } \\
\text { calcutta) }\end{array}$ & Piper betle Linn. & Leaves & 1100 leaves \\
\hline 5 & Kankol & Piper cubeba & Fruit & 2 Pala \\
\hline 6 & Pippali & Piper nigrum & Fruit & 2 Pala \\
\hline 7 & Haritaki & Terminalia chebula & Fruit & 1 Pala \\
\hline 8 & Bibhitak & Terminalia bellerica & Fruit & 1 Pala \\
\hline 9 & Amalaki & Emblica officinalis & Fruit & 1 Pala \\
\hline 10 & Jatifal & Myrstica Fragrans & Fruit & 1 Pala \\
\hline 11 & Ela & Eletterica cardamon & Fruit & 1 Pala \\
\hline 12 & Lavang & Sygium aromaticum & $\begin{array}{l}\text { Pushpakalika } \\
\text { (bud of flower) }\end{array}$ & 1 Pala \\
\hline 13 & Nagkeshar & Messua ferrea & Stigma & 1 Pala \\
\hline 14 & Madhu(Honey) & - & - & 100 Pala \\
\hline 15 & Jal (Water) & - & - & 1 Drona + 150 Pala \\
\hline 16 & Gud (Jaggery) & - & - & 300 Pala \\
\hline
\end{tabular}

Method of Preparation:

\section{(A) PREPARATION OF DRAVA DRAVYA}

1. Tambula Patra was cut into small pieces, the rest of the raw materials were individually reduced (size reduction) into yavakuta choorna/coarse powder with pounding machine and were put into the tinned vessel.

2. Madhu was added to the above mixture followed by water.

3. The water used in the preparation was previously boiled and cooled and was of 
potable quality.

4. Later Dhataki flower of good quality free from stalks and leaves was added on the top of the contents in the vessel at the end and mixed again with all the contents thoroughly for three consecutive days.

(B) Mixing Of Madhur Dravya (Puran Guda):

1. After stirring for three consecutive days Puran Guda was added, thoroughly mixed and stirred well to dissolve the entire sugar content.

2. It took 20 minutes to dissolve completely.

3. Later it was filtered and measured.

4. The entire liquid was allowed for some time to cool down.

5. All the contents were mixed thoroughly using stirrer. This liquid is called as wort.

\section{(C) TRANSFORMATION}

OF WORT:

1. The above prepared liquid was carefully transferred into the clean, dry fumigated Porcelian Jar.

2. Care was taken to prevent wastage due to spillage during transfer of the contents in to the pot.

3. The mixture was poured up to $3 / 4$ th part of pot, leaving $1 / 4$ th part empty

\section{(D) SEALING OF SANDHANA PATRA}

1. The Porelean Jar was closed with a lid. Then sandhi bandhana was done with mud- layered cloth.

2. Hot water was used during plastering so as to prevent contamination during mouth-sealing with mud.

4 | Nov- 2020 | Vol. 08 ${ }^{\text {th }} \mid$ Issue: $6^{\text {th }}$
(E) Sthanvimarsha

(Placing

of sandhanpatra):

1. The porcelean jar was then kept in dhanyarashi where the temperature is more than the room temparature to carry out the process of fermentation.

2. At the time of placing, care was taken to keep the entire portion of vessel up to neck inserted/ buried inside the husk of dhanya .The husk prevents the sandhana patra from getting affected by the fluctuations in the outside temperature.

3. Thus, controlled and uniform temperature was maintained which could have facilitated the inside contents of the pot to undergo proper fermentation.

\section{TESTS FOR CONFIRMATION OF} FERMENTATION PROCESS:

The confirmation of fermentation process was done by following tests as per classics:

1. Gandha, Varna, Rasa Utpatti

2. Sound Test: When heard from outside the fermentation container, no hissing sound was heard that confirms the completion of fermentation.

3. Burning Candle test: A candle was lit and taken nearer to sandhana patra, the candle continued to burn. This was because no carbon dioxide was produced, and hence confirms the completion of fermentation.

\section{Physicochemical parameter test for Asava} (Tambulasava):

1. Determination of $\mathrm{pH}$

2. Determination of viscosity

3. Determination of specific gravity

4. Determination of total solid content

5. Determination of alcohol content

6. Determination of reducing sugars

7. Determination of non- reducing 
sugars

8. Determination of total phenolic content

\section{Indications:}

1. Arsharoga

2. Kaphodbhava Roga

3. Rasayana

4. Bala, Varna, Shukra janana

5. Ashmariroga

\section{Probable Mode of Action :}

The main ingredient of Tambulasava is Tambula leaves, which is katu, tikta, kashaya rasaatmak, Ushna veeratmak and has Agneedepak properties [3]. The other ingredients such as, Pippali is deepneya and vrushya $^{[4]}$, Nagakeshar is Aampachak ${ }^{[5]}$; Kankol is Agni deepaka and anulomaka ${ }^{[6]}$; Lavanga shows Deepan, Pachak, Ruchya, Agni vardhayti \& Anna pachyati properties $^{[7]}$; Ela is Udan \& Samaan vayu anulomaka $^{[8]}$; Pugaphala is indicated in Udaradhama whereas Triphala shows deepaka, pachaka \& Anulomana properties. The contents Tambula, Kankola, Jatiphala, Lavanga, Ela \& Pugaphala have Sugandhi properties due to which they are Ruchya to the Rasanendriya.

According to Acharya Vagbhata, Agnimandya is the main cause behind Arsharoga, he further stated that Arsha, Atisaara \& Grahani diseases are causes of each other. Thus without Agnimandya, the Samprapti of Arsha cannot occur, and as majority of ingredients of the formulation Tambulasava, shows Agni deepaka \& Pachaka properties, It is indicated in Arsha Roga.

\section{Contraindications:}

5 | Nov- 2020 | Vol. 08 ${ }^{\text {th }}$ Issue: $6^{\text {th }}$
A very high dose of $50 \mathrm{ml}$ or more, may result in the stomach irritation.

\section{Dosage :}

Adults - 10 - 20ml once or twice daily, advised after food with equal quantity of water.

Kids - In lower dosage in children above 5 years of age it can be given.

\section{Pregnancy and Lactation -}

During pregnancy, it is advisable to avoid this medicine or take it only under medical supervision. During lactation period, it can be taken in lower doses.

Fermentation Process (Modern view) ${ }^{[9]}$ :

Fermentation is a chemical change induced in a complex organic compound by the action of an enzyme (zymase), where the substance is split into more simple compounds. It is the incomplete oxidation of sugar into ethanol and carbon dioxide in the absence of oxygen, brought about by the enzymes invertase and zymase secreted by the yeast cells. The sugars are hydrolysed into simple compounds (Glucose, Fructose, etc.) by the enzyme Invertase. Then Zymase acts on this to produce alcoholic fermentation.

Step-I : $\mathrm{C}_{12} \mathrm{H}_{22} \mathrm{O}_{11}+\mathrm{H}_{2} \mathrm{O}$ Invertase $\mathrm{C}_{6} \mathrm{H}_{12} \mathrm{O}_{6}$ $+\mathrm{C}_{6} \mathrm{H}_{12} \mathrm{O}_{6}$

Sugar waterglucosefructose

Step-II : $\mathrm{C}_{6} \mathrm{H}_{12} \mathrm{O}_{6}{ }^{\text {Zymase }} \longrightarrow 2 \mathrm{C}_{2} \mathrm{H}_{5}$ $\mathrm{OH}+2 \mathrm{CO}_{2}$

Fructose

Ethanol 
carbon dioxide

In respect to the oxygen supply, two types of fermentation are mainly recognized.

- Aerobic Fermentation.

- Anaerobic Fermentation.

\section{Aerobic Fermentation}

In which the dissimulation of the substrate is accomplished by absorption of oxygen, which acts as hydrogen acceptor. E.g. Acetic acid Fermentation.

\section{Anaerobic Fermentation}

In which atmospheric oxygen does not take part but other substances such as aldehyde, pyruvic acid serve as acceptors of hydrogen. Yeast, certain bacteria and some molds are capable of fermentation.

E.g.: Alcoholic fermentation

\section{BENEFITS OF FERMENTED HERBAL PREPARATIONS}

1. Removal of sugars : Fermentation procedure renders most of the undesirable sugars, makes the product more bioavailable

2. Alcohol gradient: The fermentation procedure extracts a wider range of active ingredients from the herb than any extraction method since the menstrum undergoes a gradient of rising alcohol levels.

3. Removal of heavy metals and pesticides by yeast: Yeast cell walls naturally bind heavy metals and pesticide residues and therefore act as a natural cleansing system. For this reason, properly fermented herbal extracts can contain less toxic chemicals than regular herbals.

4. Conversion of toxins into pharmaceutical agents: Not only does fermentation remove contaminants, it can also lower the toxicity of some of the occurring toxic components in plants. Higher extraction rate due to cell rupture, active transport, and enzymatic action: Fermentation actively ruptures the cells of an herb, exposing it openly to the menstrum and microorganisms have enzymes that break down cell walls to further assist in the leaching process. Fermentation action also creates an active transport system that moves the dissolved constituents from the herbs.

\section{Disscusion:}

Tambulasava is indicated in Arsharoga, Kaphodbhava rogas and has Rasayana properties. It has Agnideepaka and agnipachaka properties thus can be used in all Agnimandyajanya diseases. It contains $10-12 \%$ self generated alchohol. It is mentioned in Arsharogadhikar in Gadanigraha. There are no other references of this formulation mentioned in other classics. It is the only medicinal formulation of Tambula leaves and can prove as powerful medicine among other asavas as all contents used in preparation have high therapeutic properties.

\section{Conclusion:}

Tambulasava is a medicinal fermented formulation where microbes initiate alchohol formulation that helps in extraction of active principles and thereby increases the bioavailability of the ingredients. In theses dosage forms, multiple ingredients are used having therapeutic values and are transformed to liquid form that is safe, potent and palatable. The microbial transformation that takes place durng the 
process potentiates the drug and also preserves the formulation.

Thus, it can be concluded that Tambulasava is one of the important and unexplored formulation that possess great therapeutic properties due to the self-generated alchohol by fermentation.

\section{References:}

1. Gadanigraha of Vaidya Shodhala with the Vidyotini Hindi commentary by Shri Indradeva Tripathi edited by Shri Ganga Sahaya Pandeya, Chaukhamba Sanskrit series office Varanasi-I, 1968, Part 1 (Prayog Khanda-Asavadhikar) Page no 392

2. Dravyaguna Vijnana textbook by Prof. Priyavat Sharma published by Chaukhamba Bharati Academy, Varanasi, India.

3. Bhavmishra, Bhavprakash, edited with the Vidyotini Hindi Commentary, by Shri Brahma Shankar Mishra and Shri Rupalaji Vaisya. Varanasi: Chowkhambha Sanskrit Bhavan; 2007, Guduchyadi varga, page no. 272

4. Bhavmishra, Bhavprakash, edited with the Vidyotini Hindi Commentary, by Shri Brahma Shankar Mishra and Shri Rupalaji
Vaisya. Varanasi: Chowkhambha Sanskrit Bhavan; 2007 Haritkyadi varga, page no. 15

5. Bhavmishra, Bhavprakash, edited with the Vidyotini Hindi Commentary, by Shri Brahma Shankar Mishra and Shri Rupalaji Vaisya. Varanasi: Chowkhambha Sanskrit Bhavan; 2007, Karpuradi varga, page no. 230

6. Bhavmishra, Bhavprakash, edited with the Vidyotini Hindi Commentary, by Shri Brahma Shankar Mishra and Shri Rupalaji Vaisya. Varanasi: Chowkhambha Sanskrit Bhavan; 2007, karpuradi varga, page no. 258.

7. Bhavmishra, Bhavprakash, edited with the Vidyotini Hindi Commentary, by Shri Brahma Shankar Mishra and Shri Rupalaji Vaisya. Varanasi: Chowkhambha Sanskrit Bhavan; 2007, Karpuradi varga, page no. 219

8. Bhavmishra, Bhavprakash, edited with the Vidyotini Hindi Commentary, by Shri Brahma Shankar Mishra and Shri Rupalaji Vaisya. Varanasi: Chowkhambha Sanskrit Bhavan; 2007, Karpuradi varga, page no. 219

9. https://en.wikipedia.org/wiki/Fermentatio $\underline{\mathrm{n}}$

Conflict of Interest: Non Source of funding: Nil

Cite this article:

"Review on Tambulasava - A fermented Ayurvedic formulation."

Baban Rathod, Sachin Sheth, Vishakha Vivek Sonawane

Ayurlog: National Journal of Research in Ayurved Science- 2020; (8) (6):01- 07 